\title{
ПАМЯТИ Т. Н. СЕНИГОВОЙ ПОСВЯЩАЕТСЯ (1922-2020)
}

\section{(C) 2020 г. Галия Жапсарбаевна Алимжанова ${ }^{1}$}

\author{
13аместитель директора по научной части, заповедник-музей \\ «Памятники древнего Тараза», г. Тараз, Казахстан. E-mail: alimzhanova-g@bk.ru
}

Аннотация. 21 ноября 2020 г. научное археологическое сообщество понесло утрату - ушла из жизни Таисия Николаевна Сенигова - археолог, историк, крупный специалист в области изучения памятников Южного Казахстана. Именно она в свое время поставила окончательную точку в спорах о том, кто основал древний Тараз в своей знаменитой книге «Средневековый Тараз». исследования

Ключевые слова: археология, Т.Н. Сенигова, Тараз, средневековая археология,

\section{Т. Н. СЕНИГОВАНЫ ЕСКЕ АЛУҒА АРНАЛАДЫ}

(1922-2020)

\section{Ғалия Жапсарбайқызы Әлімжанова ${ }^{1}$} ${ }^{1}$ ғылыми бөлім бойынша директордың орынбасары, «Ежелгі Тараз ескерткіштері»
қорық-мұражайы, Тараз қаласы, Қазақстан. E-mail: alimzhanova-g@bk.ru

Аннотация. 21 қараша 2020 ж. ғылыми археологиялық қауымдастық орны толмас қаза - археолог, тарихшы, Оңтүстік Қазақстанның ескерткіштерін зерттеу саласындағы ірі маман Таисия Николаевна Сенигова өмірден өтті. Өзінің әйгілі «Ортағасырлық Тараз» кітабында ежелгі Таразды кім құрғаны туралы дау-дамайға нүкте қойған ғалым болатын. зерттеулер

Түйін сөздер: археология, Т.Н. Сенигова, Тараз, ортағасыр археология,

\section{IN MEMORY OF T. N. SENIGOVA}

(1922-2020)

\section{Galiya J. Alimzhanova ${ }^{1}$}

${ }^{1}$ Deputy director for a scientific part, reserve museum "Monuments of Ancient Taraz",

Taraz, Kazakhstan. E-mail: alimzhanova-g@bk.ru

Abstract. On November 21, 2020, the scientific archaeological community suffered a loss - Taisiya Senigova, an archaeologist, historian, and a major specialist in the study of monuments of South Kazakhstan, passed away. It was she who at one time put an end to the debate over who founded ancient Taraz in her famous book "Medieval Taraz".

Keywords: archaeology, Senigova T. N., Taraz, medieval archaeology, research

\section{Эпохи творит археология (Станислав Леи)}

Профессия археолог - это многогранная и интересная работа, требующая внимания, воображения и абстрактного мышления для вос- создания картины древнего мира в прошлом. Часто эту профессию сравнивают с работой хирурга, только в отличие от него, археолог аккуратно 
срезает культурный слой. Также ее сравнивают с детективной деятельностью - это поиски, разведка, факты и т.д.

Не осталось, наверное, на земле профессии, которую бы не освоила женщина. В мире можно по пальцам перечесть женщин-археологов. Имя Таисии Николаевны, женщиныархеолога, посвятившей свою профессиональную деятельность исследованиям древнего Тараза, стоит особняком среди знаменитых ученых и археологов, изучавших археологию Средней Азии.

Таисия Николаевна родилась 17 июля 1922 г., была младшей дочерью известного предпринимателя города Великие Луки Сенигова Николая Александровича. В начале XX в. отец ее был владельцем магазинов, торговых лавок на рынке, торговал керосином, галантерейными товарами. Многодетная семья Сениговых проживала на Большой Набережной (ныне набережная Л. Шмидта). В годы Великой Отечественной войны семья эвакуировалась, дом был взорван. В 1944 г. родители юной Таисии погибли в оккупации, а в 1942 г. на фронте погибает один из двух братьев. В том же, 1942 г., Таисия поступает в Московский государственный университет на археологическое отделение исторического факультета и одновременно на курсы военфельдшеров запаса. В 1946 г., окончив МГУ, Таисия по рекомендации профессора С. Юшкова поступает на работу в Институт истории, археологии и этнографии КазССР, ее трудовая деятельность началась именно с этого учреждения, где под руководством А. Х. Маргулана постепенно формируется отдел археологии. Здесь она проработала более 30 лет. Если заглянуть в трудовую книжку Т. Н. Сениговой, то можно увидеть всего лишь три записи: о принятии на работу младшим научным сотрудником в Академию наук КазССР от 01.12.1946 г., затем

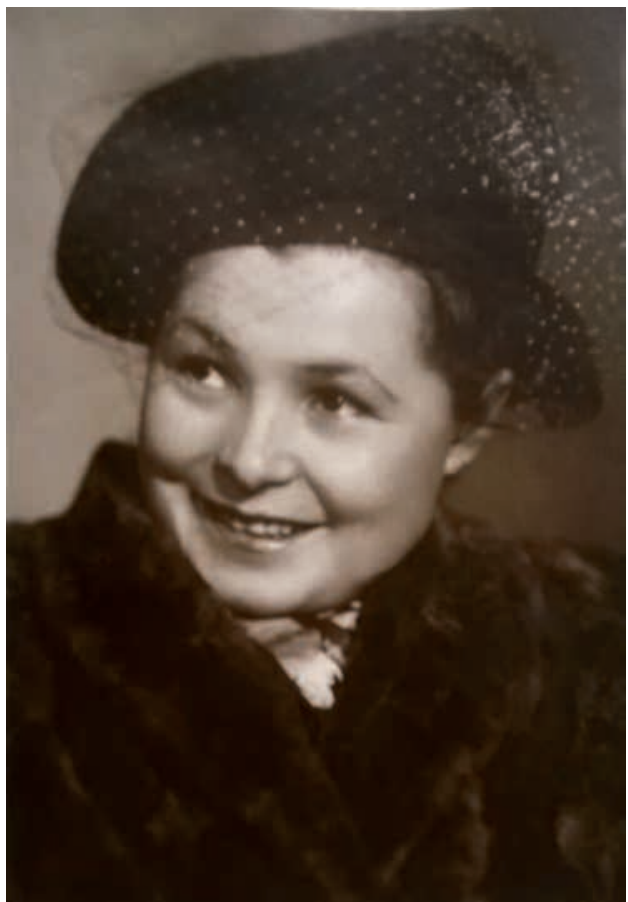

Таисия Сенигова после окончания МГУ

Taisiya Senigova after graduating from Moscow State University

запись от 28.12.1960 г. об утверждении в должности старшего научного сотрудника отдела археологии и дата - 28.11.1977 г., когда она была освобождена от занимаемой должности в связи с уходом на пенсию. В трудовую книжку также записаны многочисленные благодарности и премирования. Так, 21.02.1964 г. ее премировали как автора и составителя монографии «Археологические исследования северного склона Каратау»; премирована в честь 50-летия СССР и издания на высоком научном теоретическом уровне книги «Средневековый Тараз». В 1975 г. ей была объявлена благодарность за активную научную и общественную работу. Одно из традиционных направлений казахстанской археологии было связано с изучением средневековых городов, городской культуры и урбанизации общества. Значительная часть творческой био- 
графии Таисии Николаевны Сениговой связана с изучением памятников Южного Казахстана. Выпускница кафедры археологии была специалистом в области средневековой археологии, она стала известной благодаря своим исследованиям в Таразе и позднее в Туркестане.

В 1953 г. Т. Н. Сенигова руководила Западно-Казахстанской археологической экспедицией, в результате работы которой были обнаружены стоянки эпохи неолита, бронзы и раннего железа. В 1958 г. Таразская экспедиция, руководимая Таисией Николаевной, в районе Кулана открыла место изготовления каменных изваяний VIII-VIII вв., где было найдено семь целых изваяний и значительное число обломков и отбросов камня, оставшихся на месте при изготовлении фигур. По предположению археолога К. А. Акишева, высокое совершенство каменных скульптур показыва- ет, что у тюрок были специальные каменотесы-ваятели.

В 60-е годы XX в. значительные по объему раскопки проводились на территории одного из древнейших городов Казахстана - Таразе. Была уточнена хронология городища, собраны комплексы керамики, стекла, изделий из металла, получены сведения о жилище. На основе анализа этих материалов появился ряд статей и монография Т. Н. Сениговой о средневековом Таразе (1972).

Во второй половине XX в. город Тараз начал интенсивно развиваться и застраиваться, и многие памятники археологии уходили под застройку современного города. На территории городища Тараз уже во время археологических изысканий функционировал колхозный рынок, застраивается центральная площадь, стадион «Динамо», прокладываются городские коммуникации, таким образом, древ-

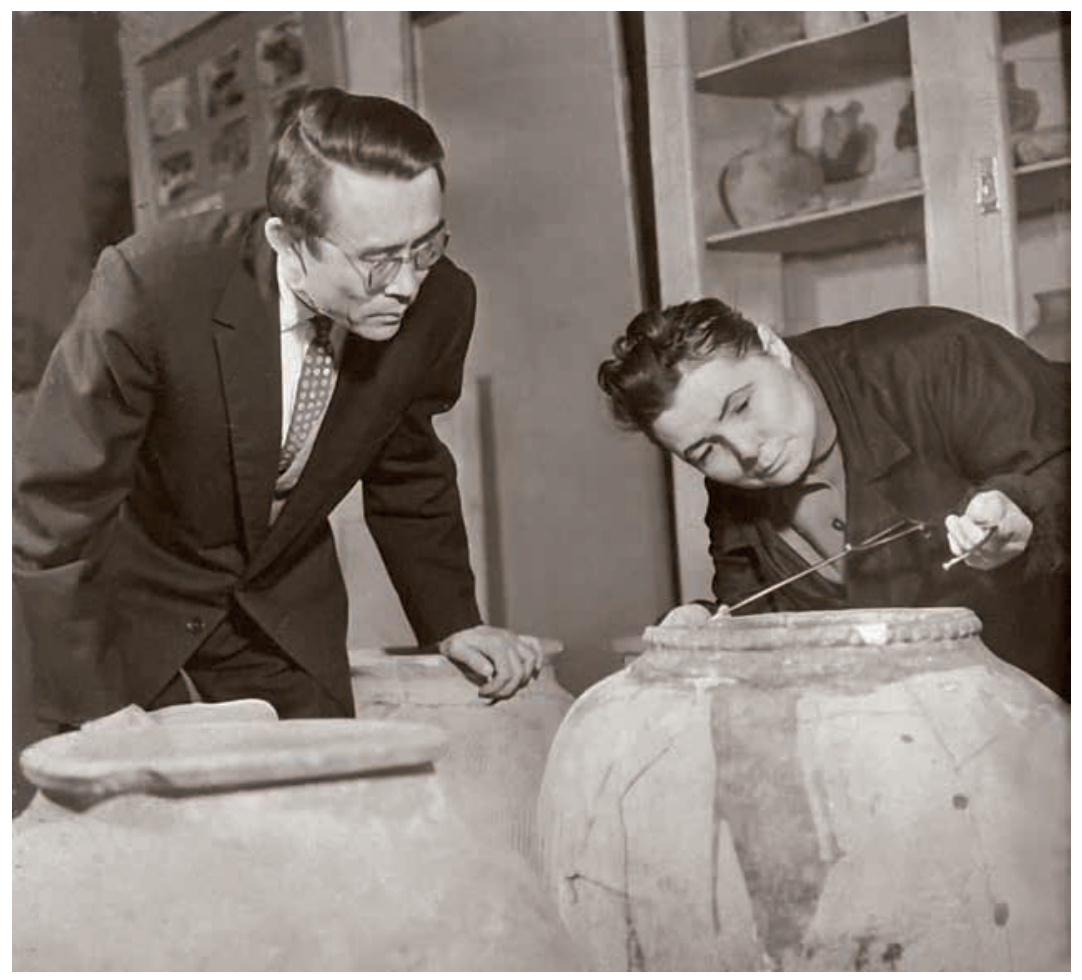

Акишев К.А. и Сенигова Т.Н.

Akishev K.A. and Senigova T.N. 
ний город практически теряет свои очертания в топографии современного города. В книге Таисия Николаевна дает описание сохранности древнего города: «В настоящее время (начало 1960-х гг.) древний Тараз полностью исчез под строениями г. Джамбула. Возвышавшаяся когда-то на 8,5-10 м над городом территория цитадели сейчас заасфальтирована. На месте юго-восточной части шахристана, некогда расчлененной буграми древних построек, возведены дома и пролегают две улицы: Атабека (в наст. время - ул. Артема) и Акмолинская. Центральная часть шахристана застроена ларьками и магазинами. В западной части цитадели расположены крытые ряды базара. Лишь по восточному склону холма - бывшей стене шахристана, которая проходит вдоль улицы Промышленной (в наст. время - ул. Аккозиева), все еще в срезе прослеживаются многометровые толщи культурного слоя, зольные прослойки и обрывки сырцовых стен. На территории западного рабада, еще в XIX в. занятой мусульманским кладбищем, среди многочисленных бугров удалось не только проследить границы города и его стены, но и изучить неизвестный ранее комплекс древних построек... На расстоянии от 3 до 40 км от города на равнинной местности Таласской долины располагаются остатки древних городов и крепостей. Здесь же можно встретить остатки древних магистральных оросительных каналов и обрывки сложной системы лабиринтов оборонительных валов» [Сенигова, 1972, с. 26].

Благодаря проведенным топографическим съемкам экспедиции были составлены планы и схемы археологических памятников Тараза с заложенными раскопами, проведена фотофиксация. В данной работе T. Н. Сенигова стремилась последовательно рассказать о тех изменениях, которые претерпел Тараз в эпоху Средневековья. Они произошли в его топографии, материальной культуре, коснулись хозяйства, социального строя, идеологии и этнической истории населения этого района.

Таисия Николаевна проводит классификацию керамических изделий, дает детальное описание орнаментации сосудов, форм и т.д. Данные научные материалы сегодня легли в основу создания на территории центральной части древнего города историко-культурного комплекса «Древний Тараз», а книга Т. Н. Сениговой «Средневековый Тараз» является ценнейшим научным источником по истории древнего Тараза.

Имя Таисии Николаевны Сениговой навсегда вписано в археологическую летопись древнего Тараза, а ее труды остаются верным «компасом» для казахстанских археологов.

\section{Список основных научных трудов Т. Н. Сениговой*}

Автореферат:

1. Керамика городища Алтын-Асар. Опыт хронологической периодизации, построенной на материалах Хорезмской экспедиции Академии наук СССР 1946-1951 гг.: автореф. дис. ... канд. ист. наук. М., 1954. 14 с.

Монография:

1. Средневековый Тараз. Алма-Ата: Наука, 1972. 228 с.

* Список составил Е. Ш. Акымбек. Прим. ред. 
Статьи:

1. Хорезмская экспедиция и ее исследования на территории Казахстана // Вестник АН КазССР. 1949. № 7 (52). С. 62-66.

2. О работе Хорезмской экспедиции в Казахстане // Вестник АН КазССР. 1950. № 1 (58). С. 98-99.

3. Археологические экспедиции 1950 года // Вестник АН КазССР. 1951. № 1. C. $134-137$.

4. Находки кремня в западных районах чинка Усть-Урта и в Приаральских Кзылкумах // Известия АН КазССР. 1951. Вып. 3. С. 122-124. C. 63-69.

5. Раскопки на городище Алтын-Асар // Вестник АН КазССР 1952. № 7 (88).

6. Отчет о работе Западно-Казахстанской археологической экспедиции 1953 года // Труды ИИАЭ АН КазССР. 1956. Т. 1. Археология. С. 140-156.

7. К изучению технических особенностей керамики низовьев Сыр-дарьи // Труды ИИАЭ АН КазССР. 1959. Т. 7. С. 215-230.

8. Монетовидный календарь // Труды ИИАЭ АН КазССР (Археология). 1961. T. 12. C. 41-47.

9. Поселение Актобе // Археологические исследования на северных Каратау. Труды ИИАЭ им. Ч.Ч. Валиханова. 1962. Т. 14. С. 57-82.

10. Наскальные изображения у поселения Актобе // Археологические исследования на северных склонах Каратау. Тр. ИИАЭ им. Ч.Ч. Валиханова. 1962. T. 14. С. 87-97.

11. Основные пути формирования топографии раннесредневекового Тараза (V-IX вв.) // Известия АН КазССР. Сер. обществ. 1966. № 5. С. 69-78.

12. К вопросу о генезисе культуры Семиречья (VI в. до н.э. - XII в. н.э.) // Вестник АН КазССР, 1967. № 4 (264). С. 69-76.

13. Вопросы идеологии и культов Семиречья // Новое в археологии Казахстана. Алма-Ата: Наука, 1968. С. 58-66.

14. Осветительные приборы Тараза и связь их с культом огня // СА. 1968. C. 208-225.

15. Новые находки в Семиречье // По следам древних культур Казахстана. АлмаАта: Наука, 1970. С. 277-289.

16. О назначении двух стеклянных сосудов из Тараза // Поиски и раскопки в Казахстане. Алма-Ата: Наука, 1972. С. 209-212.

17. Орнаментальные узоры на керамических сосудах VI-IX веков // В глубь веков. Алма-Ата: Наука, 1974. С. 119-143.

18. Уникальное культовое сооружение Аулие Кумчик-Ат в районе г. Туркестана // Прошлое Казахстана по археологическим источникам. Алма-Ата: Наука, 1976. C. 105-121.

19. Культовые сооружения около мавзолея Ходжи Ахмеда Ясеви // Археологические исслдеования в Отраре. Алма-Ата: Наука, 1977. С. 42-58.

20. Керамика городища Туркестан из верхнего строительного горизонта (XVIIXVIII вв.) // Археологические памятники Казахстана. Алма-Ата: Наука, 1978. С. 171-187.

21. Изобразительный мотив льва в прикладном искусстве древнего Казахстана // Археологические исследования древнего и средневекового Казахстана. Алма-Ата: Наука-Ғылым, 1980. С. 65-81 (в соавт. с Бурнашевой Р.3.).

Мақала туралы ақпарат / Информация о статье / Information about the article. Жариялауға қабылданды / Принята к публикации / Accepted for publication: 30.11.2020. 